\title{
Z BADAŃ NAD SYSTEMEM GRODZISK Z WCZESNEGO OKRESU EPOKI ŻELAZA NA OBSZARZE PODOLA. WSTĘPNE WYNIKI PRAC EKSPEDYCJI INSTYTUTU PRAHISTORII UNIWERSYTETU IM. ADAMA MICKIEWICZA W OBRĘBIE GRODZISKA W SEVERINİVCE ${ }^{1}$, OBWÓD WINNICA
}

\section{SYSTEM OF EARLY IRON AGE HILL FORTS IN PODOLIA. PRELIMINARY RESULTS OF ARCHAEOLOGICAL INVESTIGATIONS OF THE EARLY IRON AGE HILLFORT IN SEVERYNIVKA, VINNYTSKA' OBLAST', CARRIED OUT BY THE EXPEDITION OF THE INSTITUTE OF PREHISTORY, ADAM MICKIEWICZ UNIVERSITY}

\author{
Marcin Ignaczak \\ Instytut Prahistorii, Uniwersytet im. Adama Mickiewicza \\ ul. Św. Marcin 78, 61-809 Poznań, Poland \\ Jakub Affelski \\ Pracownia Archeologiczno-Konserwatorska „Szpila” \\ Grabówiec 93b, 06-100 Pułtusk, Poland \\ Yuriy Boltrik \\ Instytut Archeologii Akademii Nauk Ukrainy \\ Bohaterów Stalingradu 12, 254655 Kijów, Ukraine \\ Aleksandr Šelehan' \\ Instytut Archeologii Akademii Nauk Ukrainy \\ Bohaterów Stalingradu 12, 254655 Kijów, Ukraine
}

ABSTRACT. Archaeological investigations carried out by the Institute of Prehistory of Adam Mickiewicz University at the early Iron Age hillfort in Severynivka is a part of the research project ,Fortresses of Ukraine", conducted in cooperation with the Institute of Archaeology of the National Academy of

\footnotetext{
${ }^{1}$ W artykule zastosowano zasady transliteracji określone przez Polską Normę PN-ISO 9:2000 „Transliteracja znaków cyrylickich na alfabety łacińskie”, która jest tłumaczeniem międzynarodowej normy ISO 9:1995. Jedynym wyjątkiem były nazwy geograficzne, których spolszczenia znane są od dawna (np. Winnica) oraz nazwiska autorów, transliterowane według zasad języka ukraińskiego.
} 
Sciences of Ukraine. The territory where the „fortresses” occur extends from the middle course of the Dniester and the Bug rivers, in the area defining the north-western border of the steppe and forest steppe ecological zone. The studied hillfort, dated to the late seventh and mid-sixth centuries BC is a relic of the times when Central Europe witnessed intensive contacts between nomads (Scythians), and the settled communities.

Badania Instytutu Prahistorii UAM w obrębie grodziska z wczesnej epoki żelaza w Severinìvce są częścią składową szerszego programu naukowego, noszącego nazwę „Fortece Ukrainy”, realizowanego w kooperacji z Instytutem Archeologii Akademii Nauk Ukrainy ${ }^{2}$. Ma on na celu rozpoznanie i zinwentaryzowanie grodzisk tworzących zachodnią, podolską koncentrację osadniczą, w granicach lasostepu ukraińskiego. Opisywane prace wykopaliskowe oraz prospekcje powierzchniowe, realizowane w sezonach 2008-2012, są więc prologiem szerszych zamierzeń badawczych mających na celu wyjaśnienie, jakie procesy miały wpływ na powstanie i funkcjonowanie dużych grodzisk (o powierzchni przekraczającej 5 ha) we wczesnym okresie epoki żelaza (,grodziska giganty” datowane na VI i V w. przed Chr.).

Rejon, w którym zidentyfikowano podolskie fortece, rozciąga się pomiędzy środkowym biegiem Dniestru i Bohu, na obszarach wyznaczających północnozachodnią granicę strefy ekologicznej stepu i lasostepu. Budownictwo grodowe ma tu długą historię, jednak dopiero początek epoki żelaza przynosi znaczny „,skok jakościowy" w jego rozwoju. Nigdy wcześniej zjawisko to nie było tak powszechne i nie miało tak systemowego charakteru ${ }^{3}$. Na obszarze tym zlokalizowano co najmniej 7 fortec, są to obiekty: İvankìvcì (Ivankivtsi $\left.{ }^{4}\right)$ - Gora Bohìt, Gumencì (Humentsi) - Karmalûkova Gora, Knâginine (Kniahinin), Rudkìvcì (Rudkivtsi), Zgarok (Zharok), Severinìvka (Severynivka) oraz Nemirìv (Nemyriv) (ryc. 1).

Fakty związane z powstaniem grodów są interpretowane na wiele sposobów, a za czynniki kluczowe w wyjaśnianiu ich genezy uchodzą kwestie polityczne, społeczno-ekonomiczne, a także urbanizacyjne i militarne. W niniejszym projekcie ograniczono się do kilku podstawowych aspektów badawczych, mając na uwadze to, iż na wstępnym etapie badań najistotniejsze są kwestie genezy, zasięgu przestrzennego oraz niektórych aspektów funkcji grodów.

\footnotetext{
${ }^{2}$ Projekt wpisuje się w realizowaną od 1992 r. współpracę naukową między Instytutem Archeologii Akademii Nauk Ukrainy a Uniwersytetem im. Adama Mickiewicza w Poznaniu. Kierownikiem prac z ramienia IA NAN Ukrainy jest dr J. Boltrik, natomiast ze strony IP UAM dr M. Ignaczak, od strony naukowej wspomagani przez mgr. mgr. A. Šelehan'a (IA NAN), O. Lifantìj (IA NAN), Ł. Olędzkiego (IP UAM), J. Affelskiego (Pracownia Archeologiczno-Konserwatorska „Szpila”). We wczesnych etapach realizacji (sezony 2009-2010) badania były wspomagane przez Poznańskie Towarzystwo Prehistoryczne, Fundację Uniwersytetu Łódzkiego, a także Instytut Archeologii Uniwersytetu Łódzkiego.

${ }^{3}$ Daragan, Kašuba, Razumov 2010; Ignaczak 2012.

${ }^{4}$ Nazwa miejscowości zapisana w transliteracji języka ukraińskiego na język angielski stosowana w ogólnodostępnych portalach geograficznych (np. google maps).
} 


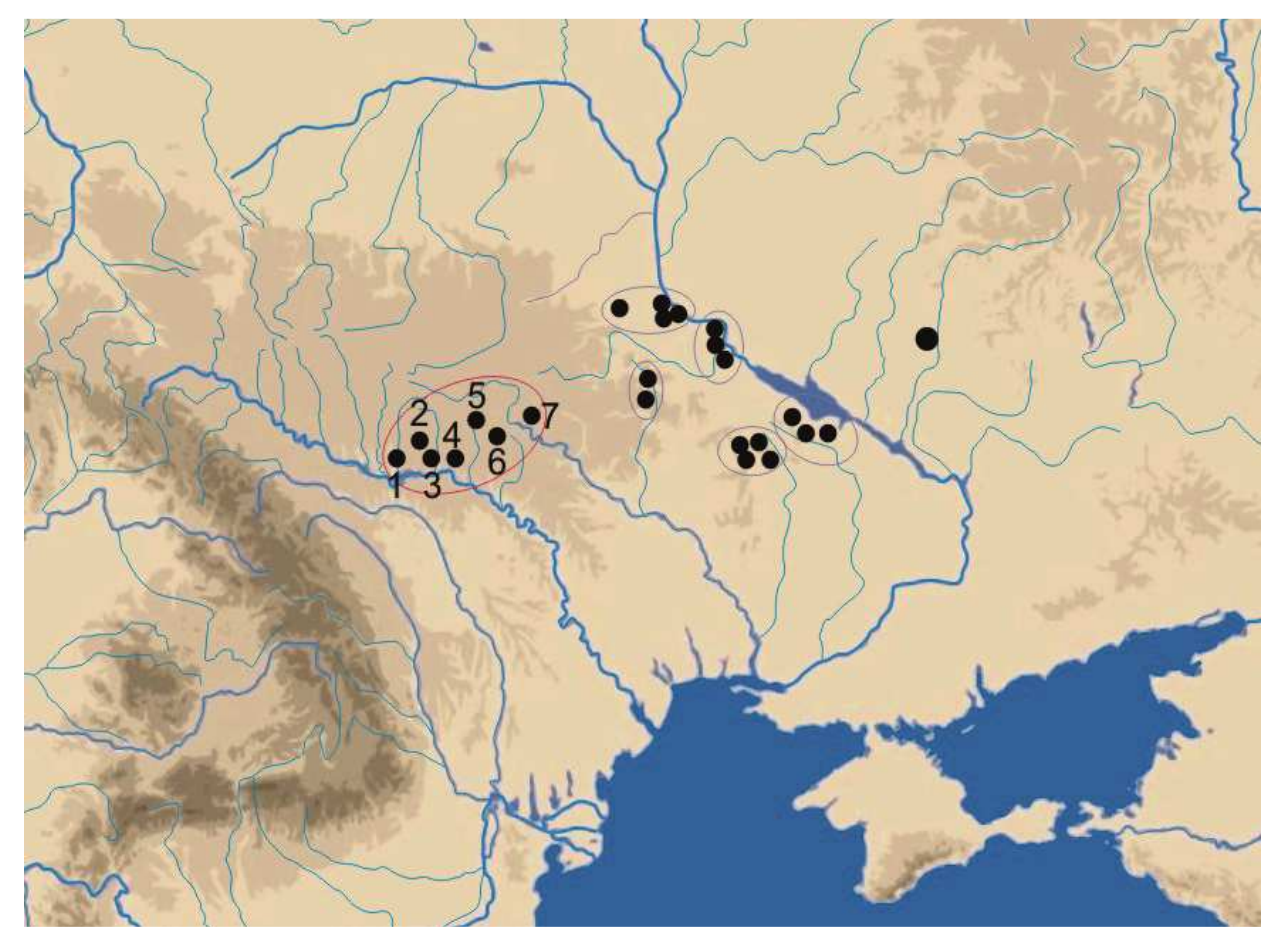

Ryc. 1. Strefy występowania grodzisk na obszarze lasostepu ukraińskiego. Kolorem czerwonym oznaczono skupisko ,podolskie"

Legenda: 1 - Ìvankìvcì (Ivankivtsi) - Gora Bohìt, 2 - Gumencì (Humentsi) - Karmalûkova Gora, 3 - Knâginine (Kniahinin), 4 - Rudkìvcì (Rudkivtsi), 5 - Zgarok (Zharok), 6 - Severinìvka (Severynivka), 7 - Nemirìv (Nemyriv)

Granice „zespołów” na podstawie definicji Y. Boltrika (1993) z uzupełnieniami autora

Fig. 1. Area within Ukrainian forest steppe with hillforts. "Podolian" concentration marked with red colour

Legend: 1 - Ivankivtsi - Gora Bohìt, 2 - Humentsi - Karmalûkova Gora, 3 - Knyahynyne, 4 - Rudkivtsi, 5 - Zgarok, 6 - Severynivka, 7 - Nemyriv

Limits of "concentrations" according to the definition by Y. Boltrik (1993), modified by the authors

Pierwszym i podstawowym problemem podjętych studiów jest zasięg przestrzenny „wczesnożelaznego” osadnictwa grodowego. Dyspersja punktów fortyfikowanych powinna dać wskazówki dla ich prawidłowej interpretacji funkcjonalnej, głównie przez odpowiedź na pytanie: czy tworzyły one układ szlakowy (,faktoryjny"), czy też może strefowy, stanowiący granicę zasięgu osadnictwa powiązaną z hipotetycznym zróżnicowaniem kulturowo-społecznym. Na obecnym etapie nie można wykluczyć żadnego z nich.

Kolejny problem wiąże się z tym, iż rejon badań można uznać za istotny punkt etapowy na „,dniestrzańskim” i ,wołyńskim” odcinku szlaku tranzytowego, łączące- 
go - od IV tysiąclecia przed Chr. - tereny zlewni Bałtyku i Morza Czarnego ${ }^{5}$. Znajduje się on w strefie pogranicza Europy Wschodniej i Zachodniej, rozumianego jako teren krzyżowania się wpływów środkowoeuropejskich społeczności agrarnych i tradycji leśnostepowych, stepowych.

Wychodząc od tak zdefiniowanych celów badawczych, zdecydowano się na rozpoczęcie prac wykopaliskowych $\mathrm{w}$ obrębie jednego z grodzisk, co powinno rozszerzyć wachlarz możliwych interpretacji, a także dać wstępną odpowiedź na temat funkcji tego rodzaju obiektów. Badania na wybranym grodzisku w Severinìvce realizowano w trzech etapach, z których dwa pierwsze przypadały na rok 2008, natomiast trzeci jest wykonywany obecnie. W planach znajduje się etap czwarty, obejmujący nieinwazyjne prace $\mathrm{w}$ obrębie zidentyfikowanych sześciu grodzisk w zachodniej strefie Podola oraz prospekcję terenową w celu poszukiwań i weryfikacji nowych obiektów. Na poszczególne stadia realizacyjne składały się: kwerenda źródeł archiwalnych, połączona ze stworzeniem wstępnej koncepcji badań jednego z grodzisk w strefie lasostepu ukraińskiego, wstępne badania powierzchniowe obszaru grodziska w Severinìvce - sezon 2008, prace wykopaliskowe na stanowisku Severinìvka 1 w sezonach 2009-2012.

W roku 2008 wykonano kwerendę materiałów archeologicznych i dokumentacji $\mathrm{z}$ badań przeprowadzonych na grodzisku z wczesnej epoki żelaza w Severinìvce (obwód Winnica) przez B. Lobaja w roku 1985 (materiały zdeponowane w Muzeum Krajoznawczym w Winnicy). W założeniach miała ona uzupełnić dotychczasowe teorie na temat funkcjonowania tego obiektu, sformułowane przez G. Smirnovą w publikacji z lat 60 . na podstawie badań $M$. Artamonova ${ }^{6}$. Dotychczasowy stan refleksji wskazywał na możliwość funkcjonowania grodziska w 2. połowie VI i w V w. przed Chr., a odkryty na nim materiał łączono z osadnictwem fazy klasycznoscytyjskiej i synchronizowano z młodszym etapem funkcjonowania grodziska w Niemirovie, podkreślając jednocześnie nikłe oddziaływania wcześniejszej kultury czarnoleskiej na obserwowane tu inwentarze źródłowe ${ }^{7}$. Podobne wnioski zaprezentował w swych sprawozdaniach z badań B. Lobaj ${ }^{8}$. Wymienieni autorzy skłaniali się ku tezom, iż w obrębie tego grodziska można identyfikować dwie fazy osadnicze (z granicą chronologiczną na poziomie 2. połowy lub końca VI w. przed Chr. ${ }^{9}$ ), przy czym obydwie miały powstać już po zaniku na obszarze Podola osadnictwa kultury czarnoleskiej. Przeprowadzone kwerendy potwierdziły wcześniejsze ustalenia, przy czym na podstawie szczegółowych analiz ceramiki nie wykluczono, iż twierdza ta mogła powstać u schyłku istnienia kultury czarnoleskiej i być zasiedlona przez jej społeczności.

\footnotetext{
${ }^{5}$ Czopek 2007; 2009; 2011; Kośko, Kločko 2011; Makohonienko 2009, Ignaczak 2011.

${ }^{6}$ Artamonov 1948; Smirnova 1961.

${ }^{7}$ Smirnova 1961, 101.

${ }^{8}$ Lobaj 1986.

${ }^{9}$ Smirnova 1961, 101.
} 
Efektem studiów było zaprojektowanie badań wykopaliskowych w południowej i zachodniej części grodziska, gdzie do tej pory osiągano najlepsze efekty, a stan zniszczenia grodu ułatwiał eksplorację (ryc. 2). Celem podstawowym było uszczegółowienie wiedzy na temat faz zasiedlenia, chronologii oraz funkcji obiektu.

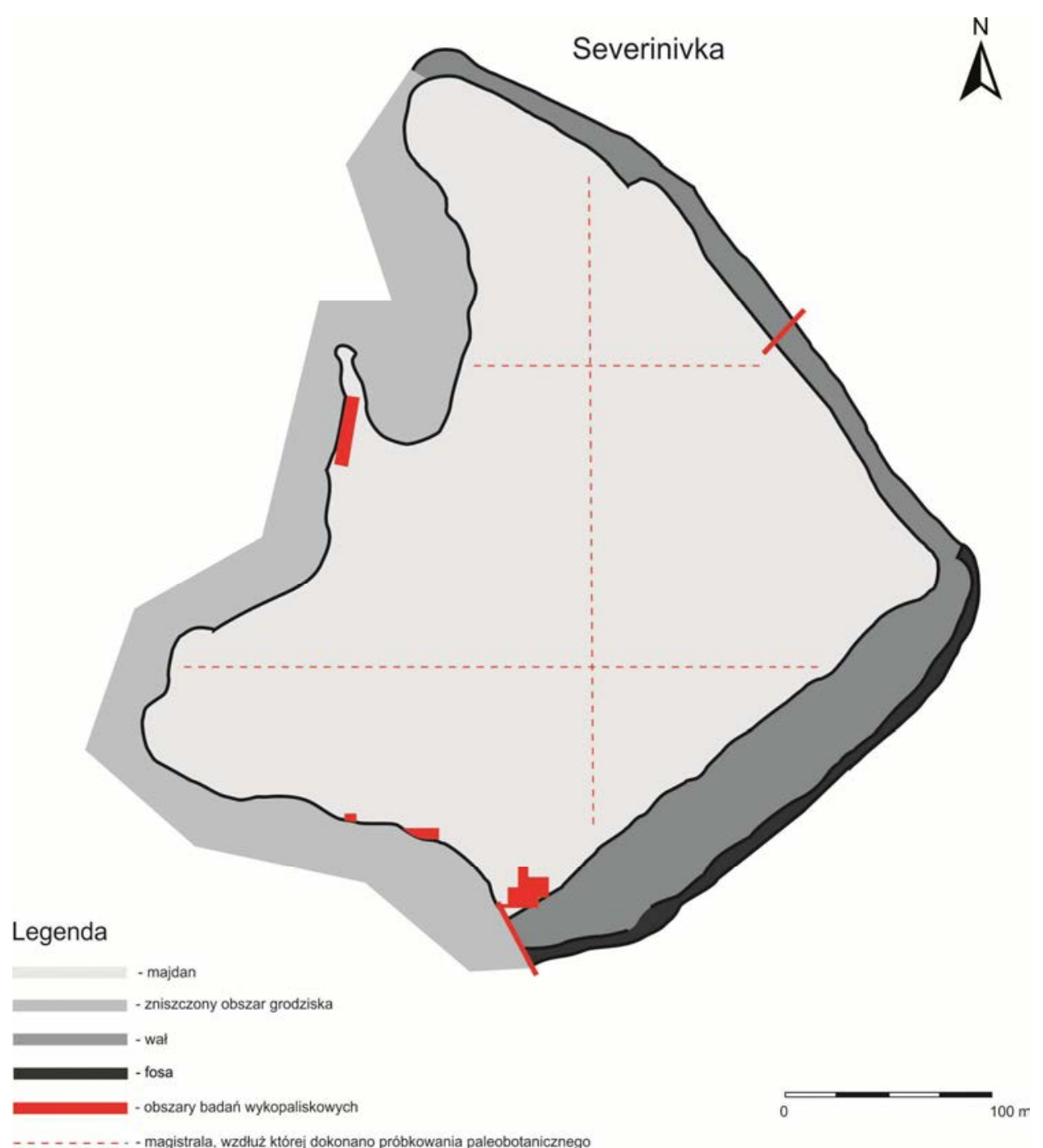

Ryc. 2. Plan grodziska w Severinìvce, obl. Winnica, stan. 1. Kolorem czerwonym zaznaczono granice wykopów, miejsca cięć profilowych w obrębie wałów, a także przebieg magistral, wzdłuż których przeprowadzono odwierty geologiczne - linia przerywana (rys. J. Affelski)

Fig. 2. Plan of the hillfort in Severynivka, Vinnytska' oblast', site 1. Limits of trenches, cross-sections of ramparts, and a main line of geological boreholes were marked with red colour - dotted line (drawing by J. Affelski) 
W latach 2009-2012 rozpoczęto eksplorację niszczejących południowo-zachodnich partii stanowiska, koncentrując się na odsłoniętym profilu wału oraz licznych osuwiskach piasku w obrębie majdanu (od strony zachodniej wyniesiony teren grodziska został naruszony licznymi wybierzyskami piasku i surowca kamiennego - ryc. 2). Taka metodyka badań spowodowała, że w trakcie trzech sezonów odsłonięto niewielką przestrzeń wykopów wytyczonych w ramach siatki arowej w obrębie majdanu (powierzchnia ok. $300 \mathrm{~m}^{2}$ ), a wysiłki koncentrowano na udokumentowaniu przekrojów fortyfikacji, a także wydobyciu źródeł zalegających w wykopach stworzonych w celu pozyskania piasku (ze względu na zniszczenie zachodniej części fortyfikacji stanowiska umożliwiło to rejestrowanie zabytków pochodzących z wewnętrznej części grodu).

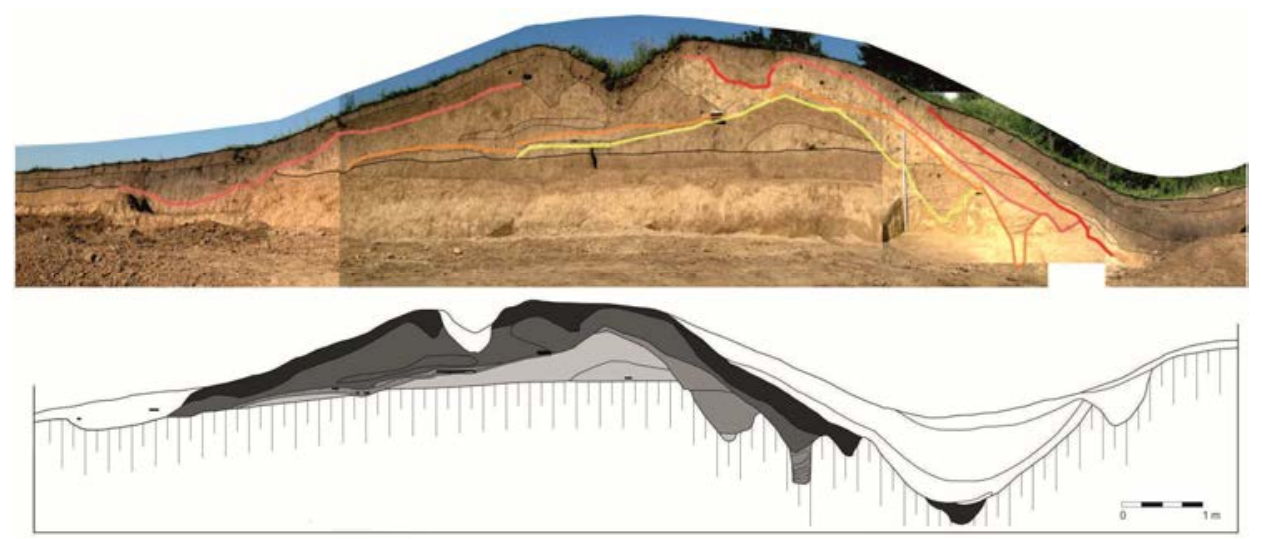

Ryc. 3. Severinìvka, obl. Winnica, stan. 1. Przekrój wału w południowej części grodziska. Kolory na fotografii oznaczają fazy budowlane (rys. A. Šelehan'; fot. Ł. Olędzki, A. Šelehan')

Fig. 3. Severynivka, Vinnytska' oblast', site 1. Cross-section of the rampart in southern part of the hillfort. Subsequent phases of construction marked with various colours (drawing by A. Šelehan'; photo by Ł. Olędzki, A. Šelehan')

Przekrój wału wykonany w dwóch punktach pozwolił na zaobserwowanie złożonych procesów jego powstania. W części południowej (ryc. 2, 3) był on stosunkowo niski (wysokość do $3 \mathrm{~m}$ ) i został usypany prawdopodobnie w trzech etapach (wynikało to z dogodnego usytuowania konstrukcji - w strefie wyniesionej). Badania w części wschodniej (kontynuowane do chwili obecnej) odsłoniły skomplikowane układy nawarstwień, których interpretacja została w ostatnim sezonie (2012) znacznie poszerzona m.in. dzięki wszechstronnym analizom geomorfologicznym (pobrane próbki są przedmiotem opracowań zespołu kierowanego przez prof. Mirosława Makohonienko z Zakładu Geologii i Paleogeografii Czwartorzędu WNGiG UAM w Poznaniu). Prawdopodobnie w tej części osady, odsłoniętej w sposób naturalny przez ukształtowanie rzeźby terenu, procesy budowlane wymagały kumulacji 


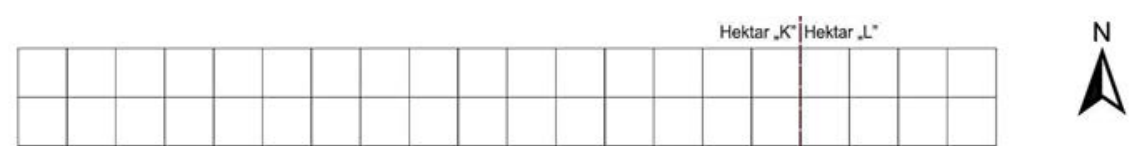

\section{Legenda}

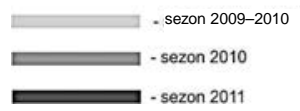

Ryc. 4. Severinìvka, obl. Winnica, stan. 1. Granice wykopów w południowej części stanowiska (rys. A. Šelehan')

Fig. 4. Severynivka, Vinnytska' oblast', site 1. Borders of trenches in the southern part of the site (drawing by A. Šelehan')

materiału skalnego i ziemnego transportowanego z zewnątrz, dla którego oparciem konstrukcyjnym był drewniany szkielet wału.

Wykopy ratownicze wykonane w obrębie majdanu (ryc. 2, 4) pozwoliły z kolei na identyfikację kilku konstrukcji wziemnych. Ich lokalizacja, bezpośrednio przy obwarowaniu grodu, utrudniała obserwacje (ze względu na przemieszczenia materiału w wyniku procesów spływowych zachodzących na wale); pomimo to udało się wyeksplorować pozostałości prawdopodobnie dwóch domostw i sześciu jam zasobowych (reprezentatywne obiekty - por. ryc. 5). W ich zasypiskach zlokalizowano liczne źródła poosadowe, w tym trzy groty scytyjskie, paciorek szklany, szpilę żelazną, fragment ceramiki greckiej, trzy kościane pobocznice oraz liczne fragmenty ceramiki naczyniowej datowanej na podstawie analiz na VII i VI w. przed Chr. (ryc. 6). Wstępne wyniki badań mikroskopowych oraz analiz fizykochemicznych pozwalają 
utożsamiać badane fragmenty ceramiki z szerszym kontekstem wytwórczości ceramicznej kultury czarnoleskiej ${ }^{10}$.

Wytwory metalowe - trzy brązowe grociki strzał oraz żelazna szpila (ryc. 7) są datowane na połowę VI w. przed Chr. ${ }^{11}$. Zostały one odkryte w obrębie warstwy kulturowej wykopów L71a oraz L81b (ryc. 4), w pobliżu reliktów zasypiska jednego z domów.

Nieco wcześniej na skali czasu sytuowane są odkryte w ramach wykopu K56d (ryc. 4), w jamie 4, kościane pobocznice (ryc. 8: 2, 3). Ich szeroki zakres odniesienia w ramach stylistyki zbieżnej z horyzontem występowania kurhanów Kelermeskich $\left(\right.$ Келермеських ${ }^{12}$ ), od połowy VII do połowy VI w. przed Chr., pozwala ostrożnie

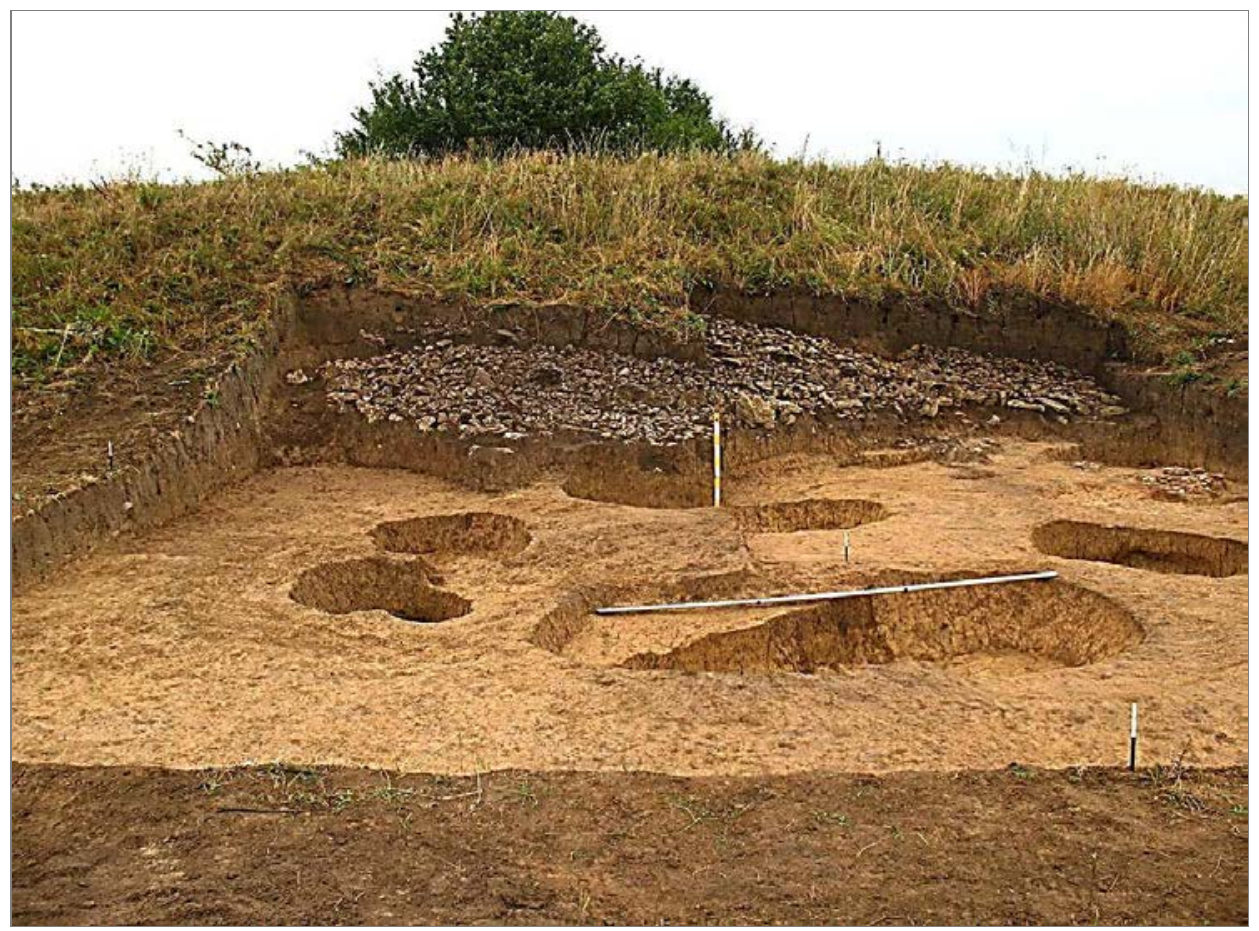

Ryc. 5. Severinìvka, obl. Winnica, stan. 1. Zarys ziemianki i jam gospodarczych w wykopie L82a (fot. M. Ignaczak)

Fig. 5. Severynivka, Vinnytska' oblast', site 1. A pithouse and storage pits in trench L82a (photo by M. Ignaczak)

\footnotetext{
${ }^{10}$ Badania nad ceramiką przeprowadzono w ramach projektu finansowanego ze środków Narodowego Centrum Nauki - przyznanych na podstawie decyzji numer DEC-2011/01/B/HS3/02172.

${ }^{11}$ Boltrik, Ignaczak, Olędzki, Šelehan' 2011, 41.

${ }^{12}$ Stylistyka ta jest reprezentowana przez widoczne na pobocznicach symbole gryfów - Boltrik, Lifantìj, Šelehan' 2012, 151.
} 

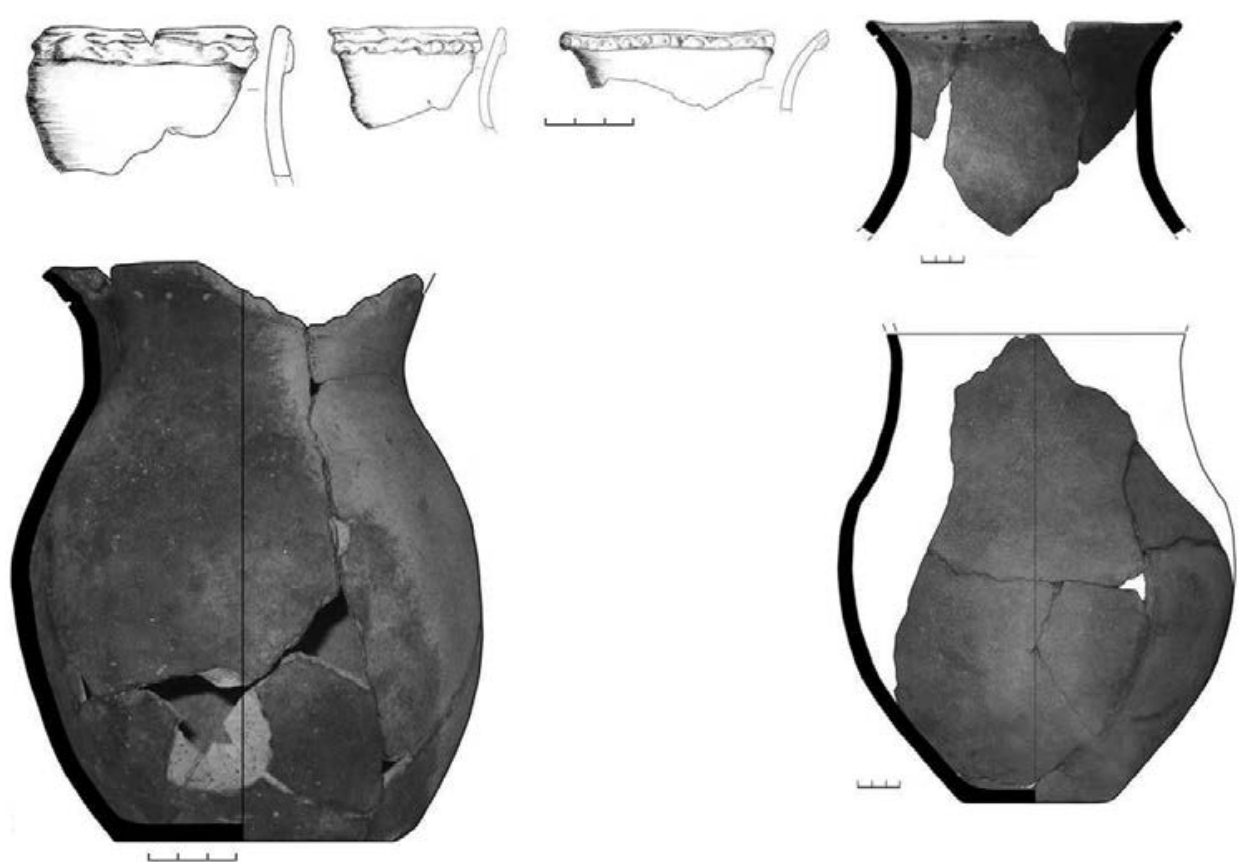

Ryc. 6. Severinìvka, obl. Winnica, stan. 1. Wybór ceramiki naczyniowej (rys. A. Šelehan') Fig. 6. Severynivka, Vinnytska' oblast', site 1. Selection of pottery (drawing by A. Šelehan')
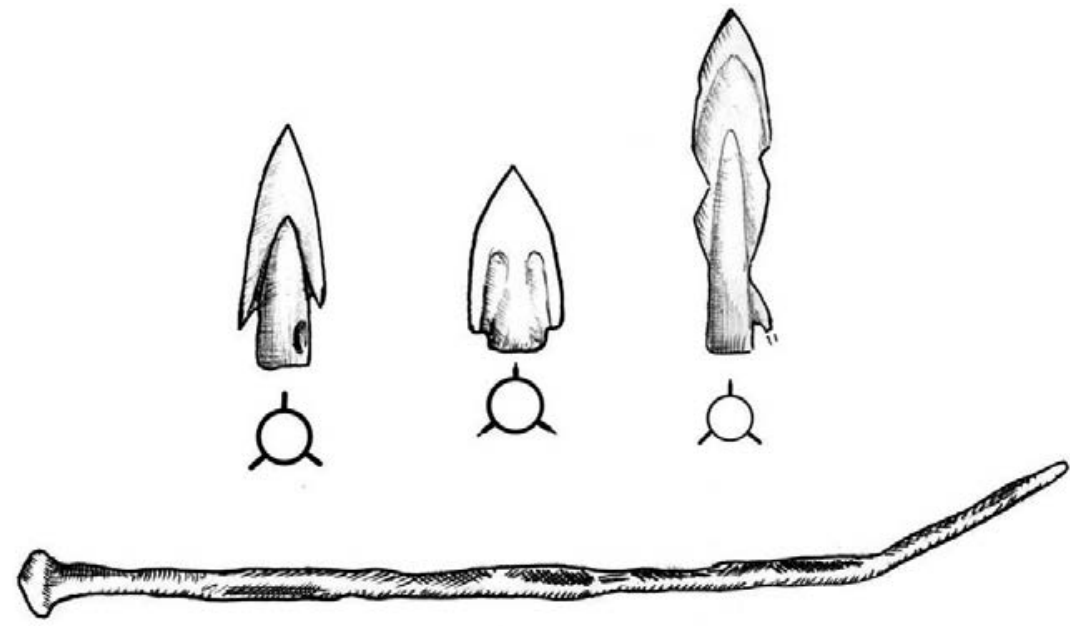

Ryc. 7. Severinìvka, obl. Winnica, stan. 1. Wybór przedmiotów metalowych z obrębu wykopów L71a oraz L81b (rys. A. Šelehan')

Fig. 7. Severynivka, Vinnytska' oblast', site 1. Selection of metal items from trenches L71a and L81b (drawing by A. Šelehan') 

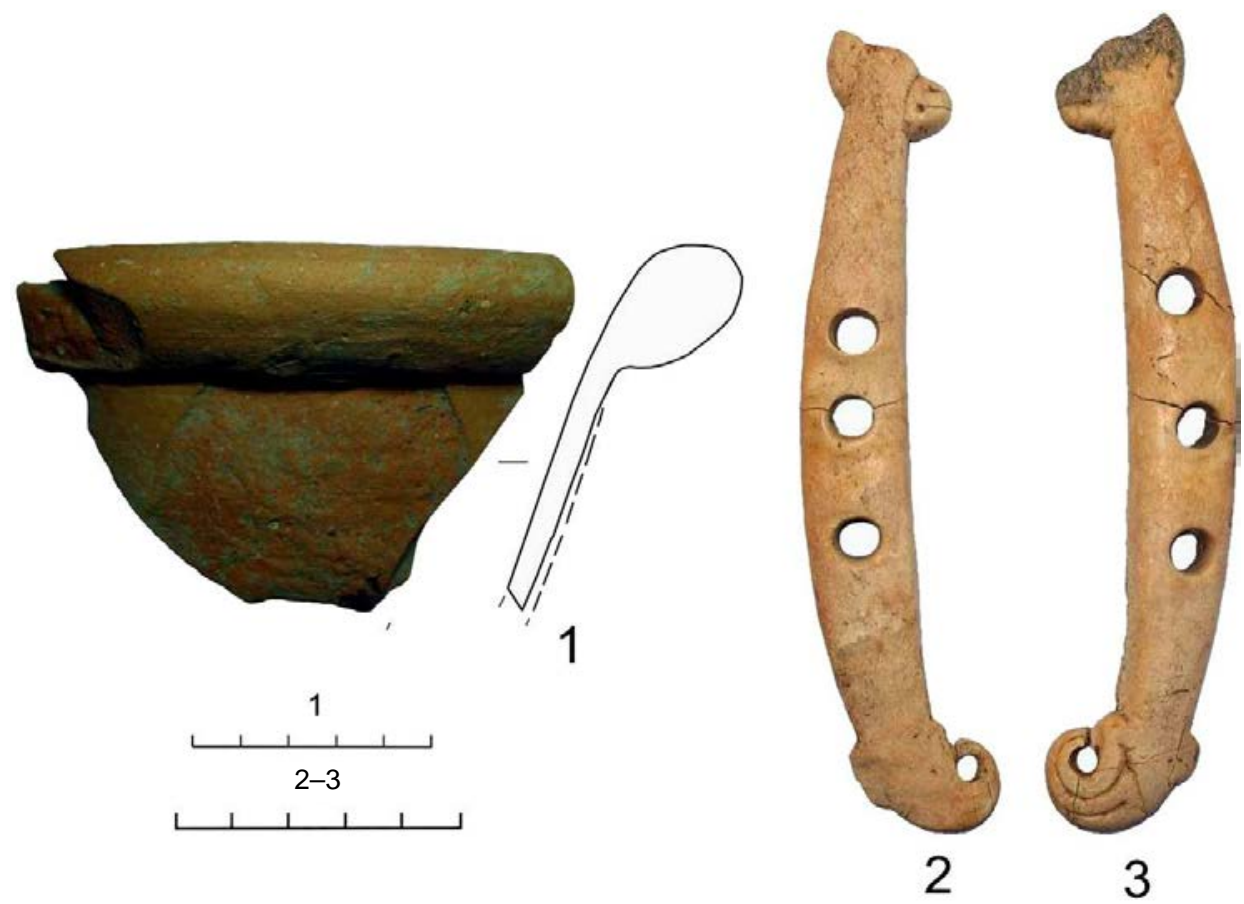

Ryc. 8. Severinìvka, obl. Winnica, stan. 1. Wykop K56d, jama 4: 1 - fragment amfory; 2, 3 - pobocznice kościane (fot. A. Šelehan')

Fig. 8. Severynivka, Vinnytska' oblast', site 1. Trench K56d, pit 4: 1 - fragment of an amphora; 2, 3 - bone cheekpieces (photo by A. Šelehan')

łączyć je z datowaniem brązowych grocików. Pobocznice te nie mają bezpośrednich analogii formalnych na obszarze lasostepu, lecz powielają wzorce funkcjonalne spotykane na grodzisku w Niemirovie ${ }^{13}$. Do horyzontu tych znalezisk przyporządkowano także odkryty w tej samej jamie co pobocznice fragment greckiej amfory, pochodzącej z pracowni lokalizowanych w Samos (ryc. 8: 1) i datowanej między końcem VII a trzecią ćwiercią VI w. przed Chr. ${ }^{14}$.

Zabytki te pozwalają przesunąć wstecz datowania grodziska poczynione przez G. Smirnovą ${ }^{15}$ i B. Lobaja ${ }^{16}$, a wówczas bardziej prawdopodobny dla jego funkcjonowania wydaje się interwał pomiędzy końcem VII a połową VI w. przed Chr. Odpowiadałoby to $\mathrm{w}$ zarysie chronologii procesów związanych $\mathrm{z}$ aktywizacją czynnika

\footnotetext{
${ }^{13}$ Smirnova 1996.

${ }^{14}$ Levinskij 2012, 244.

${ }^{15}$ Smirnova 1961.

${ }^{16}$ Lobaj 1986.
} 
koczowniczego na obszarze Europy Środkowej ${ }^{17}$. Odpowiadają im m.in. zniszczenia osiedli obronnych nad środkowym Dnieprem (Trachtemiriv ${ }^{18}$ ), a nieco później na terenie Słowacji $\left(\right.$ Smolenice $\left.^{19}\right)$, a także na obszarach Niżu Polskiego (Wicina ${ }^{20}$; Kamieniec $^{21}$ ).

Te wstępne wyniki badań nie pozwalają jeszcze na rozwiązanie podstawowego problemu, jakim jest całościowa interpretacja dotycząca funkcjonowania ,severinivskiego grodziska" w przestrzeni oraz relacji z innymi podobnymi konstrukcjami rozmieszczonymi w niedalekiej odległości. Już w trakcie prac wykopaliskowych pojawił się postulat weryfikacji dotychczasowych rezultatów poprzez prospekcję nieinwazyjną podobnych grodzisk. Efekty wykonanych badań mogą zmienić stan wiedzy o społeczeństwach strefy lasostepu ukraińskiego u progu epoki żelaza oraz o mechanizmach i sposobach recepcji/transformacji przez nie wzorców z nadczarnomorskich centrów kulturowych.

\section{BIBLIOGRAFIA}

Artamonov M.I.

1948 Arheologičeskie issledovaniâ v Ûžnoj Podolii (Vinnickoj oblasti) v 1948 g., Vestnik $L G U 11$.

Boltrik J.

1993 Osnovnì skupčennâ poselens'kih struktur v Seredn'omu Pridnìprov'ï, Doslìdžennâ starožitnostej Ukrä̈ni. Tezi dopovidej naukovoï konferenciü Muzeû istoričnih koštovnostej Ukrä̈ni - filìalu Nacìnal'nogo muzeû istorï Ukraïni, Kiïv.

Boltrik J., Ignaczak M., Olędzki Ł., Šelehan’ O.

2011 Doslìdžennâ Severinìvs'kogo gorodiŝa [w:] Arheologičnì doslidžennâ v Ukraïnì 2010, red. D. Kozak, Kiïv-Poltava, s. 41-42.

Boltrik J., Lifantìj O., Šelehan’ O.

2012 Doslìdžennâ Severinìvs'kogo gorodiŝa [w:] Arheologičnì doslidžennâ v Ukraïnì 2011, red. D. Kozak, Kiïv, s. 150-152.

Čambal R.

2007 Súčasti ochrannej šupinovej zbroje zo Smolenic-Molpira, Zbornik Slovenského Národného Múzea, CI - Archeológia 17, s. 47-56.

Bukowski Z.

1977 The Scythian influence in the area of Lusatian Culture, Wrocław. Chochorowski J.

1984 Die Vekerzug-Kultur - Frage ihrer Genese und Chronologie, Acta Archaeologica Carpatica 23, s. 99-161.

\footnotetext{
${ }^{17}$ Chochorowski 2009, 107.

${ }^{18}$ Fìalko, Boltrik 2003, 76-78.

${ }^{19}$ Čambal 2007, 52 n; Chochorowski 2009, 107-108.

${ }^{20}$ Kołodziejski 1971; Chochorowski 1984.

${ }^{21}$ Delekta 1937; Bukowski 1977, 182; Chochorowski 1984; 2009.
} 
2009 „Halsztatyzacja” wschodniej części Kotliny Karpackiej [w:] Tarnobrzeska kultura

Czopek S.

2007 Środkowoeuropejska rubież kulturowa - między Wschodem a Zachodem w epoce brązu i wczesnej epoce żelaza [w:] U źródet Europy Środkowo-Wschodniej: pogranicze polsko-ukraińskie w perspektywie badań archeologicznych, red. M. Dębiec, M. Wołoszyn, Rzeszów, s. 109-125.

2009 The Role of the Dniester Route - the San River in the Bronze and Early Iron Ages [w:] Routes between the seas: Baltic - Boh - Bug - Pont from the $3^{\text {rd }}$ to the middle of the $1^{\text {st }}$ millennium BC, Baltic-Pontic Studies 14, red. A. Kośko, V. Klochko, Poznań, s. 475-489.

2011 Rola szlaku Dniestr - San w epoce brązu i we wczesnej epoce żelaza [w:] Między Battykiem a Morzem Czarnym. Szlaki międzymorza IV-I tys. przed Chr. Archaeologia Bimaris. Dyskusje, t. IV, red. M. Ignaczak, A. Kośko, M. Szmyt, Poznań, s. 453-463.

Daragan M., Kašuba M., Razumov S.

2010 Geoinformacionnyj analiz černolesskoj fortifikacii (10.-9. vv. do n.e., pravoberež'e srednego Dniepra): Poisk ob"âsnitel'noj modeli, Revista Arheologică SN 5/2, Chişinău.

Delekta J.

1937 Badania na grodzisku łużyckim z wczesnej epoki żelaza w Kamieńcu nad Wisłą na

Fìalko O., Boltrik Û. Pomorzu, Z Otchtani Wieków 12, s. 124.

$2003 \quad$ Napad skifiv na Trahtemirivs'ke gorodišče, Kiïv.

Ignaczak M.

2009 The Role of Baltic-Black Sea Routes in the Development of Lusatian Culture Societies in the Decline Bronze and Early Iron, Baltic-Pontic Studies 14, s. 390-400.

2011 Rola szlaków międzymorza w rozwoju społeczeństw kultury łużyckiej w schyłku epoki brązu i w początkach epoki żelaza [w:] Między Battykiem a Morzem Czarnym. Szlaki międzymorza IV-I tys. przed Chr. Archaeologia Bimaris. Dyskusje, t. IV, red. M. Ignaczak, A. Kośko, M. Szmyt, Poznań, s. 387-396.

2012 Grodziska strefy lasostepu pontyjskiego we wczesnej epoce żelaza. Wstęp do dyskusji, Acta Universitatis Lodziensis, Folia Archaeologica 28, s. 173-186.

Kołodziejski A.

1971 Badania zespołu osadniczego ludności kultury łużyckiej z okresu późnohalsztackiego w Wicinie, pow. Lubsko, w latach 1966-1969, Sprawozdania Archeologiczne 23, s. 93-108.

Levinskij A.N.

2012 Grečeskie amfory na getskih pamâtnikah lesostepi Dnestrovsko-Prutskogo meždureč’â centry i ritmy postupleniâ, Stratum Plus 3, Ellinstvo i Iranstvo, s. 243-274.

Lobaj B.I.

1986 Žitlovì kompleksi gorodiŝa bìlâ sela Mežirova na Vìnničinì [w:] Tezi dopovìdej četvertoï Vìnnic'koü oblasnoï ìstoriko-kraeznavčoï konferenciï, Vìnnicâ.

Makohonienko M.

2009 Natural Scientific Aspects of Prehistoric and Early Historic Transit Routes in the BalticPontic Cultural Area [w:] Routes Between the Seas: Baltic-Boh-Bug - Pont from the $3^{\text {rd }}$ to the Middle of the $1^{\text {st }}$ Millennium BC, Baltic-Pontic Studies 14, red. A. Kośko, V. Klochko, Poznań, s. 19-71.

Smirnova G.I.

1961 Severinovskoe gorodiŝe (po materialam ûgo-podol'skoj èkspedicii 1947-1948, 1953 gg.), Arheologičeskij sbornik Gosudarstvennogo Ėrmitaža 2, s. 88-103.

1996 Nemirovskoe gorodiŝe - obŝaâ harakteristika pamâtnika VIII-VI vv. do n.e., Arheologiâ 4, s. 67-84. 


\section{SYSTEM OF EARLY IRON AGE HILL FORTS IN PODOLIA. PRELIMINARY RESULTS OF ARCHAEOLOGICAL INVESTIGATIONS OF THE EARLY IRON AGE HILLFORT IN SEVERYNIVKA, VINNYTSKA' OBLAST', CARRIED OUT BY THE EXPEDITION OF THE INSTITUTE OF PREHISTORY, ADAM MICKIEWICZ UNIVERSITY}

\section{S u m m a r y}

Archaeological investigations carried out by the Institute of Prehistory of Adam Mickiewicz University at the early Iron Age hillfort in Severynivka is a part of the research project "Fortresses of Ukraine", conducted in cooperation with the Institute of Archaeology of the National Academy of Sciences of Ukraine. The territory where the Podolian "fortresses" occur extends from the middle course of the Dniester and the Southern Bug rivers, in the area marking the north-western border of the steppe and forest steppe ecological zone. There were at least seven hillforts recorded in the area, namely: Ivankivtsi - Gora Bochit, Humentsi - Karmaliukova Gora, Knyahynyne, Rudkivtsi, Zgarok, Severynivka, and Nemyriv (Fig. 1).

Therefore, the first and basic problem of the undertaken studies appears the incidence of early Iron Age defensive settlements, while their dispersion my suggest their proper functional interpretation, mainly by answering the question whether they formed a track system, or rather zoned one, comprising the limes of a settlement related to the possible cultural and social diversity. At this stage, none of the two should be excluded.

Another problem emerges from the fact that the study area should be considered as an important staging point within a "Dniester" and "Volyn" stretch of a transit route linking - from the fourth millennium BC - the drainage basins of the Baltic and the Black Seas. It is situated in the border zone of Eastern and Western Europe, defined as a crossroad of the influences from Central European agrarian communities and forest steppe/steppe traditions.

Starting from the so-defined research objectives it was decided to begin excavations at one of the hillforts, which should expand the range of possible interpretations, and also provide a preliminary explanation of the function such structures had been meant for. The investigations at the selected hillfort in Severynivka were carried out in three stages, the first two of them in 2008, while the third being executed recently. The fourth stage is also planned, comprising non-invasive investigation at the identified six hillforts in western Podolia and field walking to find and verify new structures.

Between 2009 and 2012 the part of the site being prone to destruction had been excavated, focusing on the exposed profile of a rampart and numerous slides of sand within the bailey (elevated parts of the hillfort had been damaged from the west with numerous sandpits and traces of stone raw material exploration - Fig. 2). The artefacts collected at the site suggest it dating from the period towards the end of the seventh and mid-sixth centuries BC. This would correspond to the chronology of the processes associated with activation of nomads in Central Europe, the time when several defensive settlements were destroyed, e.g. in the middle Dnieper (Trachtemiriv), in Slovakia (Smolenice), and in the Polish Lowland (Wicina; Kamieniec). 